\title{
Some Properties of Probiotic Yoghurt Produced for Babies by Adding Fruit Puree, Containing B. infantis, B. bifidum, B. longum, L. paracasei
}

\begin{abstract}
Didem Sözeri Atik ${ }^{1, a}$, Fatma Coşkun ${ }^{1, b, *}$
${ }^{1}$ Food Engineering Department, Faculty of Agriculture, Tekirdă̆ Namik Kemal University, 59030 Süleymanpasa/Tekirdăg, Turkey *Corresponding author

A R T I C L E I N F O A B S T R A C T

Research Article

Probiotic yoghurt with fruit was produced to enrich the intestinal flora of infants and to prevent various ailments in infants when the flora is inadequate. Peach, apple and pear purees (10\% and $20 \%$ each), cow milk, milk powder, starter culture (combination of Streptococcus thermophilus, Lactobacillus delbrueckii ssp. bulgaricus, Bifidobacterium infantis, Bifidobacterium bifidum, Bifidobacterium longum and Lactobacillus paracasei) were used in the production of probiotic yogurt for babies. Some properties of yoghurt samples were investigated during fermentation and on the $1^{\text {st }}, 7^{\text {th }}, 14^{\text {th }}$ and $21^{\text {st }}$ days of storage. After ten hours of fermentation, the lowest $\mathrm{pH}$ was observed in samples with apple puree. It has been determined that syneresis increases with increasing concentrations of fruit purees. The water holding capacity was less in yoghurts containing fruit puree compared to control yoghurt and in $20 \%$ fruit puree compared to yoghurts containing $10 \%$ fruit puree. The number of L. bulgaricus generally increased in all samples during storage. It was determined that the number of $S$. thermophilus in control sample was higher than other samples during storage. The number of L. paracasei and Bifidobacterium spp. decreased during storage. While the control sample remained probiotic until the $14^{\text {th }}$ day of storage, other samples lost its probiotic properties before the $7^{\text {th }}$ day of storage. Considering that the number of probiotic microorganisms in a probiotic product should be at least $10^{6}-10^{7} \mathrm{CFU} / \mathrm{g}$ according to $\mathrm{FAO}$, it has been decided that the most suitable fruits for probiotic yogurt with fruit puree are peach and apple, respectively. Considering the structural features, it is more appropriate to use $10 \%$ fruit puree, and considering the probiotic feature, it is more appropriate to use $20 \%$ fruit puree. Choosing the appropriate packaging and fixing suitable storage conditions will help probiotic microorganisms to preserve their vitality for a long time.
\end{abstract}

\section{Introduction}

Some lactic acid bacteria isolated from the gastrointestinal tract of humans and animals are known as probiotics (Saccaro et al., 2009). Yoghurt is one of the most popular foods in terms of transporting probiotic microorganisms. With the use of probiotic bacteria in yoghurt production, the health benefits of the product are increased, while the quality of the product is positively affected (Comak Gocer et al., 2016). Yoghurt is rich in protein, calcium, phosphorus and riboflavin. Probiotic culture also contributes favorably to the sensory properties of the product (Kristo et al., 2003). The buttery acetaldehyde flavor, which is felt predominantly in traditional yoghurt, is not felt in these products (Comak Gocer et al., 2016).

Probiotics develop slowly in milk because they do not have essential proteolytic activity (Saccaro et al., 2009). The addition of Lactobacillus delbrueckii ssp. bulgaricus and Streptococcus thermophilus is required to shorten the fermentation time (Shah and Lankaputhra, 1997).

$S$. thermophilus one of the classic yoghurt starter bacteria, due to its oxygen-consuming properties, prepares the anaerobic conditions required especially for Bifidobacterium spp. and promotes their development (Ozer, 2006). Streptococci ferment fructose, mannose and lactose (Sagdic and Arici, 2010). Due to this feature, it can be quite active in fruit yoghurt.

In addition to its positive effects on health, Lactobacillus paracasei is recommended as a suitable microorganism in the production of fermented milk due to its organoleptic properties (Xanthopoulos et al., 2000). In a study, L. paracasei isolated from healthy people showed antibacterial and anticandidal activities against oral pathogens such as, Streptococcus mutans, Streptococcus salivarius, Streptococcus sanguis, Staphylococcus aureus, 
Actinomyces viscosus, Porphyromonas gingivalis, Candida albicans, Cancida tropicalis and Candida grabata (Sookkhee et al., 2001). In developing countries where environmental conditions are generally insufficient diarrhea attacks are encountered in infants and children. Fermented milk products have been reported to reduce the duration of diarrhea by half in children with diarrhea. In addition to organic acids produced by probiotic bacteria, bacteriocins and inhibitory proteins such as lactocidin, acidolin, acidophilin, lactacium-B have antimicrobial effects on pathogens (Ozer, 2010).

Although the proportion of Bifidobacterium species varies according to the type of nutrition, as people get older, their numbers in the digestive system of people decrease and their species also changes. Bifidobacterium spp. constitute $25 \%$ of the total population in adults and 95\% in newborn babies (Larpent and Larpent Gourgaut, 1997). Predominant species in breastfeeding infants are $B$. longum, $B$. infantis and $B$. breve. Predominant species in infants and children fed with food are $B$. adolescentis, $B$. infantis, B. breve, B. bifidum and B. longum (Salminen et al., 2004).

Bifidobacteria exhibit phosphotase activity, which can increase the absorption of protein from breast milk. Some Bifidobacterium species produce vitamins $\mathrm{B}_{1}, \mathrm{~B}_{9}$ and $\mathrm{B}_{12}$ (Ceyhan and Alic, 2012). B. infantis mostly produces thiamine (vitamin $\mathrm{B}_{1}$ ), folic acid (vitamin $\mathrm{B}_{9}$ ), nicotinic acid and biotin (vitamin $\mathrm{B}_{7}$ or $\mathrm{H}$ ) (Salminen et al., 2004).

Since the importance of intestinal flora in babies has been understood, foods containing probiotics and prebiotics have been produced for feeding babies (Ceyhan and Alic, 2012). Although breast milk is continued from the $6^{\text {th }}$ month, yoghurt, fruit juice, vegetable juice and puree should also be given to the baby (Koksal and Gokmen Ozel, 2008).

Fruits improve the nutritional value and taste of yoghurt (Cakmakci et al., 2012). Fresh vegetables and fruits are efficient sources of non-digestible carbohydrates such as vitamins, minerals, carbohydrates and cellulose, especially for preschool children. Fruits help intestinal activity due to their cellulose content (Unver and Unusan, 2005). Fibers that can be fermented in the column act as prebiotics, promoting the development of health-friendly probiotics such as lactobacilli and bifidobacteria, increasing the beneficial bacterial mass (Celik, 2013).

In this study, peach, apple and pear rich in prebiotics were used in the production of probiotic fruit yoghurt. Pear is one of the foods rich in dietary fiber. Rhamnogalacturono-oligosaccharides, which are prebiotics, are found in apples (Rastall and Maitin, 2002). In some studies, the applicability of apples as an ingredient to increase probiotic viability in foods has been noted. It is stated that apple and pear pieces are suitable material for $L$. casei immobilization due to their cellulosic structure (do Espirito Santo et al., 2011). Kourkoutas et al. (2006) stated that because cellulose is not digested, fruit pieces have a possible protective effect during passage through the intestinal tract, which may help L. casei reach the colon. In one study, apple was found to be a appropriate prebiotic for L. rhamnosus (Alegre et al., 2011).

In this study, the properties of probiotic yoghurts with fruit, rich in fiber and produced specifically for babies were examined during storage and the most suitable yoghurts were determined.

\section{Materials and Methods}

\section{Materials}

Peach, apple and pear purees, cow milk, milk powder, starter culture obtained from commercially producing companies were used as materials. Organic peach puree was obtained from HIPP Dış Tic. Ltd. Şti., Turkey. It is composed of $89 \%$ fruit, water, corn flour and vitamin C (energy $52 \mathrm{kcal}$, sugar $8 \mathrm{~g}$, fiber $1.9 \mathrm{~g} / 100 \mathrm{~g}$ peach puree). Organic apple and pear puree were obtained from Numil Gıda Ürünleri San. ve Tic. A.Ş., Turkey (Milupa Brand). They contained $99 \%$ fruit and vitamin C (energy $43 \mathrm{kcal}$, sugar $9.2 \mathrm{~g}$, fiber $1.7 \mathrm{~g} / 100 \mathrm{~g}$ apple puree, energy $55 \mathrm{kcal}$, sugar $8.5 \mathrm{~g}$, fiber $2 \mathrm{~g} / 100 \mathrm{~g}$ pear puree). Pasteurized whole cow milk (fat $3.1 \%$ and protein $2.8 \%$ ) was obtained from Ak Gıda San. ve Tic. A.Ş., Turkey (İçim brand). Medium heat skim milk powder obtained from Pınar Süt Mamülleri San. A.Ş., Turkey. The starter culture was supplied from Doğadan Bizim Gıda ve Süt Ürünleri San. ve Tic. Ltd. Şti, Turkey (Bizim Baby for Combiotic Yoghurt). It is a combination of, $L$. delbrueckii ssp. bulgaricus, $S$. thermophilus, B. infantis, B. bifidum, B. longum and $L$. paracasei.

\section{Production of Set-Type Yoghurts}

According to the company's yoghurt production instructions, $2 \mathrm{~g}$ of lyophilized culture should be inoculated in $5 \mathrm{~L}$ milk. Lyophilized culture $(2 \mathrm{~g})$ was activated by incubating for $30 \mathrm{~min}$ at $42^{\circ} \mathrm{C}$ using $100 \mathrm{~mL}$ of pasteurized milk with $5 \%$ milk powder added. After adding $5 \%$ milk powder, the milk $(4900 \mathrm{~mL})$ was pasteurized at $90^{\circ} \mathrm{C}$ for $10 \mathrm{~min}$ and then cooled to $43^{\circ} \mathrm{C}$. The activated culture was added to pasteurized milk for yoghurt production and the mix was divided into seven experimental lots, peach $(10 \%$, $20 \%)$, apple $(10 \%, 20 \%)$ and pear $(10 \%, 20 \%)$ purees and control yoghurt (before starting the main study, preliminary tests were carried out using various proportions of fruit purees and milk powder. Preliminary tests were repeated until the most structurally appropriate yoghurt was obtained). The fruit purees were added to yoghurt milk before the fermentation. In order to determine the $\mathrm{pH}$ values during fermentation, $30 \mathrm{~mL}$ of fruit puree added yoghurt milk and control yoghurt milk were put into each of $50 \mathrm{~mL} 50$ disposable polipropilen (PP) plastic packages (total $1500 \mathrm{~mL}$ ). For the analysis to be carried out on the $1^{\text {st }}, 7^{\text {th }}, 14^{\text {th }}$ and $21^{\text {st }}$ days of the storage, $125 \mathrm{~mL}$ of fruit puree added yoghurt milk and control yoghurt milk were put into each of $150 \mathrm{~mL} 28$ disposable PP plastic packages (total $3500 \mathrm{~mL}$ ). All samples were incubated at $43^{\circ} \mathrm{C}$ until the $\mathrm{pH}$ values of yoghurts were reached to 4.5 . Fermentation lasted about 10 hours at $43^{\circ} \mathrm{C}$. They were cooled at the room temperature and stored at $4^{\circ} \mathrm{C}$ for 12 hours and analysis were performed on the $1^{\text {st }}, 7^{\text {th }}, 14^{\text {th }}$ and $21^{\text {st }}$ days of store.

\section{Physicochemical Analysis}

$\mathrm{pH}$ values of samples were measured with $\mathrm{pH}$ meter (HI2002-02, Hanna Instruments, Inc., USA). Syneresis was determined according to Tamime et al. (1996). $25 \mathrm{~g}$ of sample was weighted to Whatman No.1 filter paper and 
stored at $4^{\circ} \mathrm{C}$ for 2 hours. It was calculated as the ratio of whey weight to sample weight as percentage. Titratable acidity and the total solid amount of samples were carried out using AOAC method (Helrich, 1990). For the determination of water holding capacity (WHC), $10 \mathrm{~g}$ of yoghurt was placed into falcon tube and centrifuged at $5000 \mathrm{rpm}$ for $20 \mathrm{~min}$ at $4^{\circ} \mathrm{C}$ (Celik and Bakirci, 2003). L*, $\mathrm{a}^{*}, \mathrm{~b}^{*}$ color measurements of samples were made using Konica Minolta Chorama Meter CR-5. Color measurements and total solid values of the samples were carried out on the first day of storage.

\section{Microbiological Analysis}

The counts of microorganims were determined during storage at $4^{\circ} \mathrm{C}\left(1^{\text {st }}, 7^{\text {th }}, 14^{\text {th }}\right.$ and $21^{\text {st }}$ days $)$. One gram of sample was diluted with $9 \mathrm{~mL}$ of sterile $0.1 \%(\mathrm{w} / \mathrm{v})$ peptone water (Oxoid, Basingstoke, UK), mixed with a vortex and subsequently serially diluted. The spread plate method was used to evalute of microbial counts. M17 agar (Merck, Germany) was used for enumeration of $S$. thermophilus at $37^{\circ} \mathrm{C}$ for 48 hours under aerobic conditions (Rybka and Kailasapathy, 1996). MRS agar (Oxoid CM 361, Thermo-Fisher Scientific Inc., USA) was acidified with $\mathrm{HCl}$ to reach $5.2 \mathrm{pH}$ value. It was used to determine the count of $L$. delbrueckii ssp. bulgaricus and incubated anaerobically at $37^{\circ} \mathrm{C}$ for 72 hours (Dave and Shah, 1996). The counts of $L$. paracase $i$ ssp. paracase $i$ were determined with using Vancomysin added MRS agar and incubated anaerobically at $37^{\circ} \mathrm{C}$ for 72 hours. MRS agar was supplemented with cysteine chloride and lithium mupirocin (69732, Sigma-Aldrich) to determine the count of Bifidobacterium strains. The incubation was carried out anaerobically $\left(5 \% \mathrm{CO}_{2}\right.$ atmosphere) at $37^{\circ} \mathrm{C}$ for 72 hours (Tharmaraj and Shah, 2003). After the incubation, plates were counted and results were expressed as log CFU/g.

\section{Statistical Analysis}

During the evaluation of phsicochemical and microbiological analysis results, the difference between the groups was determined using the univeriate general linear model procedure of the SPSS statistical software programme (version 18; SPSS, Inc., Chicago, IL, USA). Duncan's multiple comparison test was used to determine significant differences among the means at $\mathrm{P}<0.05$ (Duzgunes et al., 1978). All analyses and measurements were repeated in triplicates.

\section{Results and Discussion}

The fermentation of all samples was completed at the end of the $10^{\text {th }}$ hour. $\mathrm{pH}$ decreased earlier in probiotic yoghurt samples containing apple and pear puree than other samples (Table 1). In yoghurt production, the incubation period is 2.5-3.0 hours when standard cultures are used, and 6-9 hours when cultures with moderately acidifying properties are used. When $\mathrm{pH}$ decreases below 5, acid gel formation begins to appear. Coagulation is complete when the $\mathrm{pH}$ value is less than the isoelectric point $(\mathrm{pH} 4.6)$ of the casein (Ucuncu, 2005). Since probiotic bacteria growth slowly in milk, it is necessary to add yoghurt starter cultures to shorten the fermentation time (Shah and Lankaputhra, 1997). Probiotic bacteria may adversely affect the development of other starter bacteria through the metabolites they produce during fermentation and extend the fermentation process (Ozer, 2010).

\section{pH and Titratable Acidity}

The $\mathrm{pH}$ and titratable acidity of the samples containing peach, pear and apple puree $(0 \%, 10 \%$ and 20\%) were measured during cold storage of the samples. The results obtained from the $\mathrm{pH}$ and titratable acidity analysis of the samples during the storage periods are shown in Figure 1 and Figure 2. The $\mathrm{pH}$ values of yoghurt samples decreased until the $14^{\text {th }}$ day of storage. While the $\mathrm{pH}$ values of the samples containing $10 \%$ apple and $10 \%$ pear puree continued to decrease after the $14^{\text {th }}$ day of storage, the $\mathrm{pH}$ values of the other samples increased. The findings of the current study are consistent with those of do Espirito Santo et al. (2012) who found fluctuating results for $\mathrm{pH}$ values of control sample during cold storage. Demirci et al. (2017) demonstrated that $\mathrm{pH}$ values of the yoghurt samples decreased with the time of cold storage. The $\mathrm{pH}$ results of samples were found significant at the $\mathrm{P}<0.05$ level. The $\mathrm{pH}$ values of samples containing $10 \%$ apple puree and $10 \%$ pear puree decreased considerably at the end of the storage. The current study found that the $\mathrm{pH}$ values of yoghurt samples containing $10 \%$ and $20 \%$ apple puree are 4.14 and 4.26 on the $21^{\text {st }}$ day of storage. The present findings seem to be consistent with other research which found the $\mathrm{pH}$ value of apple pomace added yoghurts were 4.3 (Wang et al., 2019). The data of $\mathrm{pH}$ can be compared with the data in Figure 2 which shows the titratable acidity values of samples. Generally, the $\mathrm{pH}$ of samples showed consistency with their titratable acidity. The titratable acidity values of yoghurt samples varied from $0.84 \%$ to $1.17 \%$ lactic acid during cold storage for all samples. This finding is in agreement with do Espírito Santo et al. (2012) findings which showed that the titratable acidity of passion fruit added yoghurt ranged from 0.87 to $0.74 \%$ lactic acid. As shown in Figure 2, there was an increase in the titratable acidity values. The difference between storage days in the $\mathrm{pH}$ of the yogurt sample containing $10 \%$ peach puree was insignificant $(\mathrm{P}>0.05)$

The increase in the titratable acidity values induced during the storage period was statistically significant in all samples with the exception of the control sample and sample containing $10 \%$ peach puree $(\mathrm{P}<0.05)$. The storage time was not having a significant effect in the titratable acidity of sample containing $10 \%$ peach puree. However, the titratable acidity of control samples significantly increased to the $14^{\text {th }}$ day, but then titratable acidity of the control yoghurt fell slightly. Karaca et al. (2019) produced yoghurt that fortified with the apricot fibre. They found that there has been a steadily decrease in the titratable acidity values with the increased ratio of apricot fibre (from 1.00 to $0.97 \%$ lactic acid). The findings of them seem to be consistent with the current study which showed that the increased peach ratio resulted in the lower titratable acidity (from 1.02 to $0.89 \%$ lactic acid) at the first day of the cold storage.

\section{Physicochemical Properties}

Table 2 shows syneresis and the water holding capacity results of the yoghurt samples. The reason of syneresis defined as the shrinkage of the yoghurt gel and resulted in the whey separation (Lucey, 2004). 
Table 1. $\mathrm{pH}$ values of the yoghurt milk sample during the fermentation

\begin{tabular}{l|ccccccc}
\hline Fermentation time (h) & Control & $10 \%$ Peach & $20 \%$ Peach & $10 \%$ Apple & $20 \%$ Apple & $10 \%$ Pear & $20 \%$ Pear \\
\hline 0 & $6.48 \pm 0.04^{\mathrm{Aa}}$ & $6.26 \pm 0.03^{\mathrm{Ac}}$ & $6.05 \pm 0.03^{\mathrm{Be}}$ & $6.27 \pm 0.03^{\mathrm{Ac}}$ & $6.11 \pm 0.04^{\mathrm{Ad}}$ & $6.36 \pm 0.03^{\mathrm{Ab}}$ & $6.23 \pm 0.04^{\mathrm{Ac}}$ \\
2 & $6.50 \pm 0.03^{\mathrm{Aa}}$ & $6.30 \pm 0.03^{\mathrm{Ac}}$ & $6.11 \pm 0.02^{\mathrm{Ae}}$ & $6.29 \pm 0.03^{\mathrm{Acd}}$ & $6.10 \pm 0.02^{\mathrm{Ae}}$ & $6.35 \pm 0.04^{\mathrm{Ab}}$ & $6.25 \pm 0.02^{\mathrm{Ad}}$ \\
4 & $6.51 \pm 0.04^{\mathrm{Aa}}$ & $6.30 \pm 0.02^{\mathrm{Ac}}$ & $6.10 \pm 0.03^{\mathrm{Ae}}$ & $6.31 \pm 0.02^{\mathrm{Ac}}$ & $6.14 \pm 0.04^{\mathrm{Ae}}$ & $6.38 \pm 0.02^{\mathrm{Ab}}$ & $6.24 \pm 0.02^{\mathrm{Ad}}$ \\
6 & $6.20 \pm 0.05^{\mathrm{Ba}}$ & $5.92 \pm 0.03^{\mathrm{Bc}}$ & $5.84 \pm 0.02^{\mathrm{Cd}}$ & $5.78 \pm 0.02^{\mathrm{Be}}$ & $5.47 \pm 0.03^{\mathrm{Bf}}$ & $6.03 \pm 0.04^{\mathrm{Bb}}$ & $5.87 \pm 0.03^{\mathrm{Bcd}}$ \\
8 & $5.10 \pm 0.03^{\mathrm{Ca}}$ & $4.91 \pm 0.04^{\mathrm{Cb}}$ & $4.91 \pm 0.01^{\mathrm{Db}}$ & $4.70 \pm 0.03^{\mathrm{Cd}}$ & $4.69 \pm 0.02^{\mathrm{Cd}}$ & $4.79 \pm 0.02^{\mathrm{Cc}}$ & $4.83 \pm 0.00^{\mathrm{Cc}}$ \\
9 & $4.89 \pm 0.02^{\mathrm{Da}}$ & $4.78 \pm 0.02^{\mathrm{Db}}$ & $4.74 \pm 0.02^{\mathrm{Ec}}$ & $4.57 \pm 0.01^{\mathrm{De}}$ & $4.51 \pm 0.01^{\mathrm{Df}}$ & $4.55 \pm 0.04^{\mathrm{De}}$ & $4.70 \pm 0.01^{\mathrm{Dd}}$ \\
10 & $4.84 \pm 0.00^{\mathrm{Da}}$ & $4.70 \pm 0.03^{\mathrm{Eb}}$ & $4.67 \pm 0.01^{\mathrm{Fb}}$ & $4.50 \pm 0.02^{\mathrm{Ed}}$ & $4.51 \pm 0.05^{\mathrm{Dd}}$ & $4.50 \pm 0.03^{\mathrm{Dd}}$ & $4.56 \pm 0.02^{\mathrm{Ec}}$ \\
\hline
\end{tabular}

Data are means \pm SD $(n=3)$. Lower-case letters present the differences between the different samples in the same fermentation time and upper-case letters show differences between the different fermentation times of each sample $(\mathrm{P}<0.05)$.

Table 2. Syneresis and water holding capacity (\%) values of yoghurt samples during storage

\begin{tabular}{c|ccccc}
\hline Analysis & Samples & Day 1 & Day 7 & Day 14 & Day 21 \\
\hline & Control & $28.66 \pm 4.04$ & $28.92 \pm 2.54^{\mathrm{a}}$ & $20.26 \pm 1.10^{\mathrm{cd}}$ & $29.64 \pm 0.65^{\mathrm{a}}$ \\
& $10 \%$ Peach & $30.00 \pm 1.69$ & $27.64 \pm 1.07^{\mathrm{a}}$ & $26.46 \pm 0.93^{\mathrm{b}}$ & $29.12 \pm 0.56^{\mathrm{a}}$ \\
& $20 \%$ Peach & $28.84 \pm 0.39^{\mathrm{A}}$ & $29.24 \pm 0.56^{\mathrm{A}, \mathrm{a}}$ & $30.30 \pm 0.02^{\mathrm{A}, \mathrm{a}}$ & $26.86 \pm 0.29^{\mathrm{B}, \mathrm{a}}$ \\
& $10 \%$ Apple & $24.48 \pm 3.28^{\mathrm{A}}$ & $16.14 \pm 1.27^{\mathrm{B}, \mathrm{bc}}$ & $14.50 \pm 0.19^{\mathrm{B}, \mathrm{f}}$ & $6.20 \pm 0.59^{\mathrm{C}, \mathrm{c}}$ \\
& $20 \%$ Apple & $24.66 \pm 0.08^{\mathrm{A}}$ & $23.78 \pm 0.82^{\mathrm{A}, \mathrm{ab}}$ & $21.44 \pm 1.07^{\mathrm{A}, \mathrm{c}}$ & $12.02 \pm 0.41^{\mathrm{B}, \mathrm{bc}}$ \\
& $10 \%$ Pear & $22.06 \pm 0.93^{\mathrm{A}}$ & $15.18 \pm 0.25^{\mathrm{A}, \mathrm{c}}$ & $14.90 \pm 0.02^{\mathrm{A}, \mathrm{ef}}$ & $6.44 \pm 1.72^{\mathrm{B}, \mathrm{c}}$ \\
& $20 \%$ Pear & $24.82 \pm 1.32$ & $19.10 \pm 4.10^{\mathrm{bc}}$ & $17.90 \pm 1.27^{\mathrm{de}}$ & $17.54 \pm 1.20^{\mathrm{b}}$ \\
\hline & Control & $55.90 \pm 1.27^{\mathrm{AB}, \mathrm{a}}$ & $51.05 \pm 0.91^{\mathrm{B}}$ & $58.50 \pm 1.13^{\mathrm{A}, \mathrm{a}}$ & $53.55 \pm 2.05^{\mathrm{AB}}$ \\
& $10 \%$ Peach & $55.30 \pm 0.00^{\mathrm{A}, \mathrm{ab}}$ & $51.60 \pm 1.97^{\mathrm{AB}}$ & $50.45 \pm 0.49^{\mathrm{B}, \mathrm{bc}}$ & $55.25 \pm 1.20^{\mathrm{AB}}$ \\
& $20 \%$ Peach & $55.90 \pm 4.94^{\mathrm{a}}$ & $49.20 \pm 3.11$ & $50.40 \pm 0.28^{\mathrm{bc}}$ & $53.05 \pm 0.63$ \\
& $10 \%$ Apple & $47.75 \pm 0.63^{\mathrm{C}, \mathrm{bc}}$ & $52.15 \pm 1.06^{\mathrm{B}}$ & $49.55 \pm 0.07^{\mathrm{BC}, \mathrm{bc}}$ & $55.35 \pm 0.77^{\mathrm{A}}$ \\
& $20 \%$ Apple & $46.50 \pm 0.28^{\mathrm{c}}$ & $46.25 \pm 0.49$ & $47.00 \pm 0.00^{\mathrm{c}}$ & $51.40 \pm 3.25$ \\
& $10 \%$ Pear & $48.15 \pm 0.07^{\mathrm{abc}}$ & $49.40 \pm 5.51$ & $51.30 \pm 1.55^{\mathrm{b}}$ & $54.15 \pm 0.63$ \\
& $20 \%$ Pear & $47.75 \pm 1.34^{\mathrm{B}, \mathrm{bc}}$ & $52.90 \pm 0.56^{\mathrm{A}}$ & $47.65 \pm 1.34^{\mathrm{B}, \mathrm{c}}$ & $49.40 \pm 0.56^{\mathrm{AB}}$ \\
\hline
\end{tabular}

Lower-case letters present the differences between the different samples in the same storage time and upper-case letters show differences between the storage times of each sample $(\mathrm{P}<0.05)$. The difference between storage days in the $\mathrm{pH}$ of the yogurt sample containing $10 \%$ apple puree was insignificant $(\mathrm{P}>0.05)$.

It is found that syneresis increased with the increase of the concentration of all fruit purees. The findings of the current study are consistent with those of Wang et al. (2019) who found the increased amount of the apple pomace in yoghurt resulted in high ratio of syneresis. It seems possible that these results are due to the insoluble fiber content of fruit purees. The insoluble fibers can cause an increase in syneresis values as a result of their disruption potential of gel structure (Wang et al., 2019). There were no significant differences during cold storage period of control sample, samples containing $10 \%$ peach puree and $20 \%$ pear puree $(\mathrm{P}>0.05)$. On the other hand, the syneresis values of the other samples were found statistically important with the progress of cold storage period $(\mathrm{P}<0.05)$. The addition of peach puree increased syneresis of yoghurt samples significantly compared to yoghurts containing pear and apple puree. Sineresis was higher in samples containing $20 \%$ fruit puree than containing $10 \%$ fruit puree. The water holding capacity provide an information about the gel stability of samples (Brückner-Gühmann et al., 2019). The water holding capacity was higher in the samples containing $10 \%$ fruit puree than in the ones containing $20 \%$ fruit puree.

Color values of fruit purees s is shown in Table 3 . The total solid and color values of probiotic yogurt samples are shown in Table 4. Total solid values of probiotic yogurt samples containing fruit puree were lower than that of control sample. The increase in the fruit puree added caused a decrease in the total solid value. Except for the control yoghurt, the yoghurt sample with peach puree had the highest total solid value. In the study of Debashis Kumar et al. (Debashis Kumar et al., 2015) as the fruit pulp ratio increased in yoghurts containing papaya and watermelon pulps, total solid values decreased. In that study, as the rate of banana pulp increased, the total solid value of yoghurt increased slightly. In the same study, the total solid values of yoghurts containing fruit pulp were lower than that of the control yoghurt. These results are similar to those in our study.

Although the $\mathrm{L}^{*}$ values of the samples containing fruit puree were lower than that of the control sample, the $\mathrm{a}^{*}$ and $b^{*}$ values of the samples containing fruit puree were higher than that of the control sample. The increase in the fruit puree rates caused the $\mathrm{L}^{*}$ values to decrease and the $\mathrm{a}^{*}$ and $b^{*}$ values to increase.

\section{Microbiological Enumeration}

Microbiological analysis results are shown in Table 5. The numbers of $L$. delbrueckii ssp. bulgaricus were the highest on the $14^{\text {th }}$ day of storage, except for samples containing apple puree. L. delbrueckii ssp. bulgaricus count was higher in samples containing $20 \%$ pear puree than samples containing $20 \%$ pear puree on all days of storage. $L$. delbrueckii ssp. bulgaricus counts were higher in samples containing $10 \%$ fruit puree than samples containing $20 \%$ fruit puree. According to the statistical analysis, the differences between the days of storage and samples in terms of $L$. delbrueckii ssp. bulgaricus were significant $(\mathrm{P}<0.05)$.

The number of $S$. thermophilus was high in control yoghurt from yoghurts with fruit during storage. In addition, its numbers in samples containing $10 \%$ fruit puree were higher than those containing $20 \%$ fruit puree. It can be said that the addition of fruit puree suppressed the growth of this bacteria. 
Table 3. Colour values of fruit purees

\begin{tabular}{l|ccc}
\hline \multicolumn{1}{c|}{ Fruit Puree } & $\mathrm{L}^{*}$ & $\mathrm{a}^{*}$ & $\mathrm{~b}^{*}$ \\
\hline Peach puree & $43.66 \pm 0.01$ & $7.82 \pm 0.18$ & $33.93 \pm 0.18$ \\
Apple puree & $39.85 \pm 0.03$ & $0.25 \pm 0.01$ & $18.38 \pm 0.01$ \\
Pear puree & $40.97 \pm 0.03$ & $2.09 \pm 0.01$ & $18.74 \pm 0.00$ \\
\hline
\end{tabular}

$\mathrm{L}^{*}$ : lightness axis, $\mathrm{a}^{*}$ : green-red axis, $\mathrm{b}^{*}$ : blue-yellow axis

Table 4. Total solid (\%) and color values of yoghurt samples

\begin{tabular}{l|cccc}
\hline \multirow{2}{*}{ Yoghurts } & \multirow{2}{*}{ Total solid $(\%)$} & \multicolumn{3}{c}{ Color values } \\
\cline { 3 - 5 } & & $\mathrm{L}^{*}$ & $\mathrm{a}^{*}$ & $\mathrm{~b}^{*}$ \\
\hline Control & $16.50 \pm 0.33^{\mathrm{a}}$ & $83.92 \pm 0.03^{\mathrm{a}}$ & $-1.80 \pm 0.01^{\mathrm{g}}$ & $7.21 \pm 0.03^{\mathrm{g}}$ \\
$10 \%$ Peach & $16.14 \pm 0.21^{\mathrm{a}}$ & $80.56 \pm 0.01^{\mathrm{d}}$ & $0.19 \pm 0.01^{\mathrm{b}}$ & $11.50 \pm 0.00^{\mathrm{b}}$ \\
$20 \%$ Peach & $15.56 \pm 0.11^{\mathrm{b}}$ & $76.52 \pm 0.01^{\mathrm{g}}$ & $1.32 \pm 0.01^{\mathrm{a}}$ & $16.21 \pm 0.01^{\mathrm{a}}$ \\
$10 \%$ Apple & $15.19 \pm 0.30^{\mathrm{bc}}$ & $82.30 \pm 0.01^{\mathrm{b}}$ & $-1.17 \pm 0.02^{\mathrm{f}}$ & $8.78 \pm 0.02^{\mathrm{f}}$ \\
$20 \%$ Apple & $14.85 \pm 0.17^{\mathrm{c}}$ & $79.38 \pm 0.00^{\mathrm{f}}$ & $-0.93 \pm 0.03^{\mathrm{e}}$ & $10.21 \pm 0.05^{\mathrm{d}}$ \\
$10 \%$ Pear & $14.91 \pm 0.08^{\mathrm{c}}$ & $81.76 \pm 0.01^{\mathrm{c}}$ & $-0.87 \pm 0.02^{\mathrm{d}}$ & $9.11 \pm 0.03^{\mathrm{e}}$ \\
$20 \%$ Pear & $14.83 \pm 0.08^{\mathrm{c}}$ & $79.91 \pm 0.01^{\mathrm{e}}$ & $-0.38 \pm 0.01^{\mathrm{c}}$ & $10.51 \pm 0.02^{\mathrm{c}}$ \\
\hline
\end{tabular}

Different letters in the same column are significantly different $(\mathrm{P}<0.05)$. Results are expressed as the mean \pm standard deviation $(\mathrm{n}=3)$. *The results were given for day 1.

Table 5. The bacteria numbers of yoghurt samples during storage $(\log$ CFU/g)

\begin{tabular}{|c|c|c|c|c|c|}
\hline Bacteria & Yoghurts & Day1 & Day7 & Day14 & Day21 \\
\hline \multirow{7}{*}{ Lactobacillus delbrueckii ssp. bulgaricus } & Control & $5.30 \pm 0.06^{\mathrm{D}, \mathrm{f}}$ & $5.60 \pm 0.25^{\mathrm{C}, \mathrm{c}}$ & $5.90 \pm 0.15^{\mathrm{A}, \mathrm{e}}$ & $5.69 \pm 0.30^{\mathrm{B}, \mathrm{f}}$ \\
\hline & $10 \%$ Peach & $5.45 \pm 0.04^{\mathrm{D}, \mathrm{d}}$ & $6.18 \pm 0.60^{\mathrm{C}, \mathrm{b}}$ & $6.30 \pm 0.90^{\mathrm{A}, \mathrm{a}}$ & $6.26 \pm 0.21^{\mathrm{B}, \mathrm{a}}$ \\
\hline & $20 \%$ Peach & $5.83 \pm 0.15^{\mathrm{C}, \mathrm{a}}$ & $5.40 \pm 0.07^{\mathrm{D}, \mathrm{e}}$ & $6.18 \pm 0.70^{\mathrm{B}, \mathrm{c}}$ & $6.20 \pm 0.36^{\mathrm{A}, \mathrm{b}}$ \\
\hline & $10 \%$ Apple & $5.58 \pm 0.21^{\mathrm{D}, \mathrm{b}}$ & $6.40 \pm 0.45^{\mathrm{A}, \mathrm{a}}$ & $6.23 \pm 0.45^{\mathrm{B}, \mathrm{b}}$ & $6.11 \pm 0.30^{\mathrm{C}, \mathrm{c}}$ \\
\hline & $20 \%$ Apple & $5.51 \pm 0.15^{\mathrm{B}, \mathrm{c}}$ & $5.30 \pm 0.07^{\mathrm{C}, \mathrm{e}}$ & $5.00 \pm 0.03^{\mathrm{D}, \mathrm{f}}$ & $6.00 \pm 0.40^{\mathrm{A}, \mathrm{d}}$ \\
\hline & $10 \%$ Pear & $5.08 \pm 0.04^{\mathrm{C}, \mathrm{g}}$ & $5.30 \pm 0.09^{\mathrm{B}, \mathrm{e}}$ & $6.08 \pm 0.40^{\mathrm{A}, \mathrm{d}}$ & $5.30 \pm 0.03^{\mathrm{B}, \mathrm{g}}$ \\
\hline & $20 \%$ Pear & $5.40 \pm 0.07^{\mathrm{D}, \mathrm{e}}$ & $5.50 \pm 0.15^{\mathrm{C}, \mathrm{d}}$ & $6.30 \pm 0.60^{\mathrm{A}, \mathrm{a}}$ & $5.78 \pm 0.10^{\mathrm{B}, \mathrm{e}}$ \\
\hline \multirow{7}{*}{ Streptococcus thermophilus } & Control & $8.48 \pm 0.70^{\mathrm{A}, \mathrm{a}}$ & $8.08 \pm 0.36^{\mathrm{D}, \mathrm{a}}$ & $8.20 \pm 0.35^{\mathrm{C}, \mathrm{a}}$ & $8.26 \pm 0.40^{\mathrm{B}, \mathrm{a}}$ \\
\hline & $10 \%$ Peach & $7.54 \pm 0.05^{\mathrm{BC}, \mathrm{bc}}$ & $7.51 \pm 0.15^{\mathrm{C}, \mathrm{b}}$ & $7.58 \pm 0.31^{\mathrm{AB}, \mathrm{b}}$ & $7.61 \pm 0.21^{\mathrm{A}, \mathrm{c}}$ \\
\hline & $20 \%$ Peach & $7.48 \pm 0.31^{\mathrm{A}, \mathrm{c}}$ & $7.30 \pm 0.76^{\mathrm{B}, \mathrm{d}}$ & $7.11 \pm 0.76^{\mathrm{C}, \mathrm{e}}$ & $7.08 \pm 0.25^{\mathrm{C}, \mathrm{f}}$ \\
\hline & $10 \%$ Apple & $7.32 \pm 0.72^{\mathrm{A}, \mathrm{d}}$ & $7.40 \pm 0.57^{\mathrm{C}, \mathrm{c}}$ & $7.48 \pm 0.91^{\mathrm{B}, \mathrm{d}}$ & $7.60 \pm 1.52^{\mathrm{A}, \mathrm{c}}$ \\
\hline & 20\% Apple & $7.08 \pm 0.45^{\mathrm{C}, \mathrm{e}}$ & $6.85 \pm 0.55^{\mathrm{D}, \mathrm{e}}$ & $7.50 \pm 1.00^{\mathrm{A}, \mathrm{cd}}$ & $7.48 \pm 0.58^{\mathrm{B}, \mathrm{d}}$ \\
\hline & $10 \%$ Pear & $7.58 \pm 0.40^{\mathrm{B}, \mathrm{b}}$ & $7.48 \pm 0.13^{\mathrm{C}, \mathrm{b}}$ & $7.54 \pm 0.10^{\mathrm{B}, \mathrm{c}}$ & $7.70 \pm 0.15^{\mathrm{Ab}}$ \\
\hline & $20 \%$ Pear & $7.53 \pm 0.21^{\mathrm{A}, \mathrm{bc}}$ & $6.51 \pm 0.01^{\mathrm{C}, \mathrm{f}}$ & $6.36 \pm 0.04^{\mathrm{C}, \mathrm{f}}$ & $7.30 \pm 0.45^{\mathrm{B}, \mathrm{e}}$ \\
\hline \multirow{7}{*}{ Lactobasillus paracasei } & Control & $5.00 \pm 0.30^{\mathrm{A}, \mathrm{e}}$ & $4.00 \pm 0.06^{\mathrm{D}, \mathrm{f}}$ & $4.79 \pm 0.15^{\mathrm{B}, \mathrm{bc}}$ & $4.48 \pm 0.02^{\mathrm{C}, \mathrm{g}}$ \\
\hline & $10 \%$ Peach & $5.00 \pm 0.45^{\mathrm{C}, \mathrm{e}}$ & $4.00 \pm 0.04^{\mathrm{D}, \mathrm{f}}$ & $5.60 \pm 0.15^{\mathrm{A}, \mathrm{a}}$ & $5.54 \pm 0.11^{\mathrm{B}, \mathrm{a}}$ \\
\hline & $20 \%$ Peach & $5.48 \pm 0.11^{\mathrm{A}, \mathrm{a}}$ & $4.20 \pm 0.07^{\mathrm{D}, \mathrm{e}}$ & $4.84 \pm 0.20^{\mathrm{C}, \mathrm{b}}$ & $5.00 \pm 0.30^{\mathrm{B}, \mathrm{c}}$ \\
\hline & $10 \%$ Apple & $5.00 \pm 0.35^{\mathrm{A}, \mathrm{e}}$ & $4.59 \pm 0.31^{\mathrm{C}, \mathrm{d}}$ & $4.46 \pm 0.03^{\mathrm{D}, \mathrm{e}}$ & $4.70 \pm 0.21^{\mathrm{B}, \mathrm{f}}$ \\
\hline & 20\% Apple & $5.30 \pm 0.50^{\mathrm{A}, \mathrm{b}}$ & $4.74 \pm 0.25^{\mathrm{BC}, \mathrm{c}}$ & $4.70 \pm 0.15^{\mathrm{C}, \mathrm{cd}}$ & $4.78 \pm 0.15^{\mathrm{B}, \mathrm{e}}$ \\
\hline & $10 \%$ Pear & $5.11 \pm 0.49^{\mathrm{B}, \mathrm{d}}$ & $4.95 \pm 0.36^{\mathrm{C}, \mathrm{a}}$ & $4.59 \pm 0.21^{\mathrm{D}, \mathrm{de}}$ & $5.28 \pm 0.17^{\mathrm{A}, \mathrm{b}}$ \\
\hline & $20 \%$ Pear & $5.18 \pm 0.45^{\mathrm{A}, \mathrm{c}}$ & $4.77 \pm 0.30^{\mathrm{C}, \mathrm{b}}$ & $4.00 \pm 0.03^{\mathrm{A}, \mathrm{f}}$ & $4.95 \pm 0.20^{\mathrm{B}, \mathrm{d}}$ \\
\hline \multirow{7}{*}{ Bifidobacterium spp. } & Control & $7.81 \pm 1.15^{\mathrm{A}, \mathrm{a}}$ & $6.56 \pm 0.11^{\mathrm{B}, \mathrm{a}}$ & $6.38 \pm 0.06^{\mathrm{C}, \mathrm{a}}$ & $5.18 \pm 0.05^{\mathrm{D}, \mathrm{a}}$ \\
\hline & $10 \%$ Peach & $7.32 \pm 0.07^{\mathrm{A}, \mathrm{b}}$ & $4.77 \pm 0.30^{\mathrm{B}, \mathrm{d}}$ & $4.69 \pm 0.15^{\mathrm{B}, \mathrm{c}}$ & $4.48 \pm 0.05^{\mathrm{B}, \mathrm{d}}$ \\
\hline & $20 \%$ Peach & $6.97 \pm 0.30^{\mathrm{A}, \mathrm{c}}$ & $4.70 \pm 0.10^{\mathrm{B}, \mathrm{d}}$ & $4.48 \pm 0.05^{\mathrm{B}, \mathrm{c}}$ & $4.00 \pm 0.01^{\mathrm{B}, \mathrm{g}}$ \\
\hline & $10 \%$ Apple & $6.61 \pm 0.40^{\mathrm{A}, \mathrm{e}}$ & $5.52 \pm 0.20^{\mathrm{B}, \mathrm{c}}$ & $5.49 \pm 0.05^{\mathrm{B}, \mathrm{b}}$ & $4.95 \pm 0.02^{\mathrm{B}, \mathrm{b}}$ \\
\hline & $20 \%$ Apple & $6.81 \pm 0.20^{\mathrm{A}, \mathrm{d}}$ & $5.62 \pm 0.25^{\mathrm{B}, \mathrm{b}}$ & $4.60 \pm 0.05^{\mathrm{C}, \mathrm{c}}$ & $4.38 \pm 0.03^{\mathrm{C}, \mathrm{e}}$ \\
\hline & $10 \%$ Pear & $6.41 \pm 0.50^{\mathrm{A}, \mathrm{f}}$ & $5.70 \pm 0.15^{\mathrm{B}, \mathrm{b}}$ & $4.49 \pm 0.01^{\mathrm{C}, \mathrm{c}}$ & $4.53 \pm 0.01^{\mathrm{C}, \mathrm{c}}$ \\
\hline & $20 \%$ Pear & $5.49 \pm 0.10^{\mathrm{A}, \mathrm{g}}$ & $4.90 \pm 0.25^{\mathrm{B}, \mathrm{d}}$ & $4.30 \pm 0.08^{\mathrm{C}, \mathrm{c}}$ & $4.23 \pm 0.02^{\mathrm{C}, \mathrm{f}}$ \\
\hline
\end{tabular}

Lower-case letters present the differences between the different samples in the same storage time and upper-case letters show differences between the storage times of each sample $(\mathrm{P}<0.05)$

The number of $S$. thermophilus decreased steadily from the beginning of storage in samples containing $20 \%$ peach puree. The numbers of this microorganism generally decreased until the $7^{\text {th }}$ day of storage and then increased and reached the highest level on the $21^{\text {st }}$ day of storage in samples containing $10 \%$ peach, $10 \%$ apple, $10 \%$ pear puree, but still could not exceed the number in the control sample. According to the statistical analysis, the differences between the days of storage and samples in terms of $S$. thermophilus were significant $(\mathrm{P}<0.05)$. In the study conducted by Canganella et al. (2000), inoculated yoghurt starters, L. acidophilus and B. infantis in cow milk, and they obtained a yoghurt with a $\mathrm{pH}$ of 4.5 at the end of $42^{\circ} \mathrm{C}$ incubation. On the first day of storage, the number of each microorganism was approximately $10^{8} \mathrm{CFU} / \mathrm{mL}$. Although the number of $L$. bulgaricus of plain cowmilk yoghurt sample stored at $4^{\circ} \mathrm{C}$ decreased up to the $5^{\text {th }}$ day, then increased and decreased again after the $10^{\text {th }}$ day of storage. The number of $S$. thermophilus was generally higher than L. bulgaricus. On the $10^{\text {th }}$ day of storage, the 
numbers of these microorganisms were close to each other. The situation was similar in the example of yogurt with raspberry.

The L. paracasei counts in all the samples containing puree were close to that in the control sample on the fisrt day of storage. The L. paracasei in counts all yoghurt samples decreased until the $7^{\text {th }}$ day of storage. While the number of that microorganism was higher in the samples with apple and pear puree on the $7^{\text {th }}$ day of storage, it reached the highest number in the sample containing $10 \%$ peach puree on the $14^{\text {th }}$ and $21^{\text {st }}$ days of storage. The number of $L$. paracasei was higher in the sample containing $20 \%$ apple puree than the sample containing $10 \%$ apple puree on all days of storage. In other samples, the number of L. paracase $i$ was higher in those that usually contain $10 \%$ fruit puree.

Kristo et al. (2003), in their study with fermented milk at $42^{\circ} \mathrm{C}$, they found that the number of $L$. paracase increased slightly during storage at $4^{\circ} \mathrm{C}$ for 21 days, unlike in our study. In study conducted by Pimentel et al. (2012), although the number of $L$. paracasei ssp. paracasei in set type yoghurts decreased slightly on the $14^{\text {th }}$ day of storage, it remained above $8 \log \mathrm{CFU} / \mathrm{g}$ for 28 days during storage. The number of $S$. thermophilus was higher than $9 \log$ $\mathrm{CFU} / \mathrm{g}$ in storage time. These numbers are higher than those in our study. This may be due to the high number of bacteria inoculated.

In general, Bifidobacterium spp. numbers were higher in all samples containing $10 \%$ fruit puree than all samples containing $20 \%$ fruit puree. At the beginning of storage, the number of Bifidobacterium spp. was observed mostly in the control sample and samples containing peach puree, while the number of Bifidobacterium spp. was the highest in yoghurt sample containing $10 \%$ apple puree and control sample at the end of storage. The number of Bifidobacterium spp. decreased during storage. The increase in the number of $L$. delbrueckii ssp. bulgaricus may have an effect on this.
In the study conducted by Pimentel et al. (2012), the number of L. delbrueckii ssp. bulgaricus was between 5.0$5.5 \log \mathrm{CFU} / \mathrm{g}$ and showed a slight decrease during storage. It is advantageous to decrease the number of $L$. delbrueckii ssp. bulgaricus. Because it is responsible for the lowering of the $\mathrm{pH}$. The increase in its number causes the probiotic number to decrease (Kailasapathy, 2006). According to the statistical analysis, the differences between the days of storage and samples were significant $(\mathrm{P}<0.05)$. In study conducted by Canganella et al. (2000), the B. infantis number increased to $5^{\text {th }}$ day of storage and then decreased as in this study. The number, which was $10^{7}$ on the $20^{\text {th }}$ day of storage, decreased rapidly after the $20^{\text {th }}$ day and decreased to $10^{1}$ levels on the $45^{\text {th }}$ day of storage.

In the study of Shah and Lankaputhra (1997), the number of B. longum decreased during storage. Samples of five brands of commercial claimed to contain $L$. acidophilus and B. bifidum within 2-3 days after production was supplied by Shah et al. (1995) and then they stored at $4^{\circ} \mathrm{C}$ for 5 weeks. On the first day of storage, the number of $B$. bifidum was between $10^{6}-10^{7}$ in two of these samples, while it was between $10^{3}-10^{4}$ in the other three, and it has declined sharply since the $12^{\text {th }}$ day of storage and has completely lost its vitality. B. bifidum number decreased faster than others in low $\mathrm{pH}$ samples. In a study, it was shown that acid adapted Bifidobacterium breve exhibits superior survival characteristics, in acidic conditions, in the presence of other environmental stresses such as bile, hydrogen peroxide and cold storage (Park et al., 1995). Acid resistant Bifidobacterium strains may prove useful for probiotic applications and may exhibit enhanced survival both in host environmental conditions and in food systems. Lactobacilli are generally more durable than bifidobacterial when compared to their rates of influencing from different factors (Ross et al., 2005). Lactobacilli are more resistant to low $\mathrm{pH}$ values and show more adaptation to milk and other food substrates (Lee and Salminen, 2009).

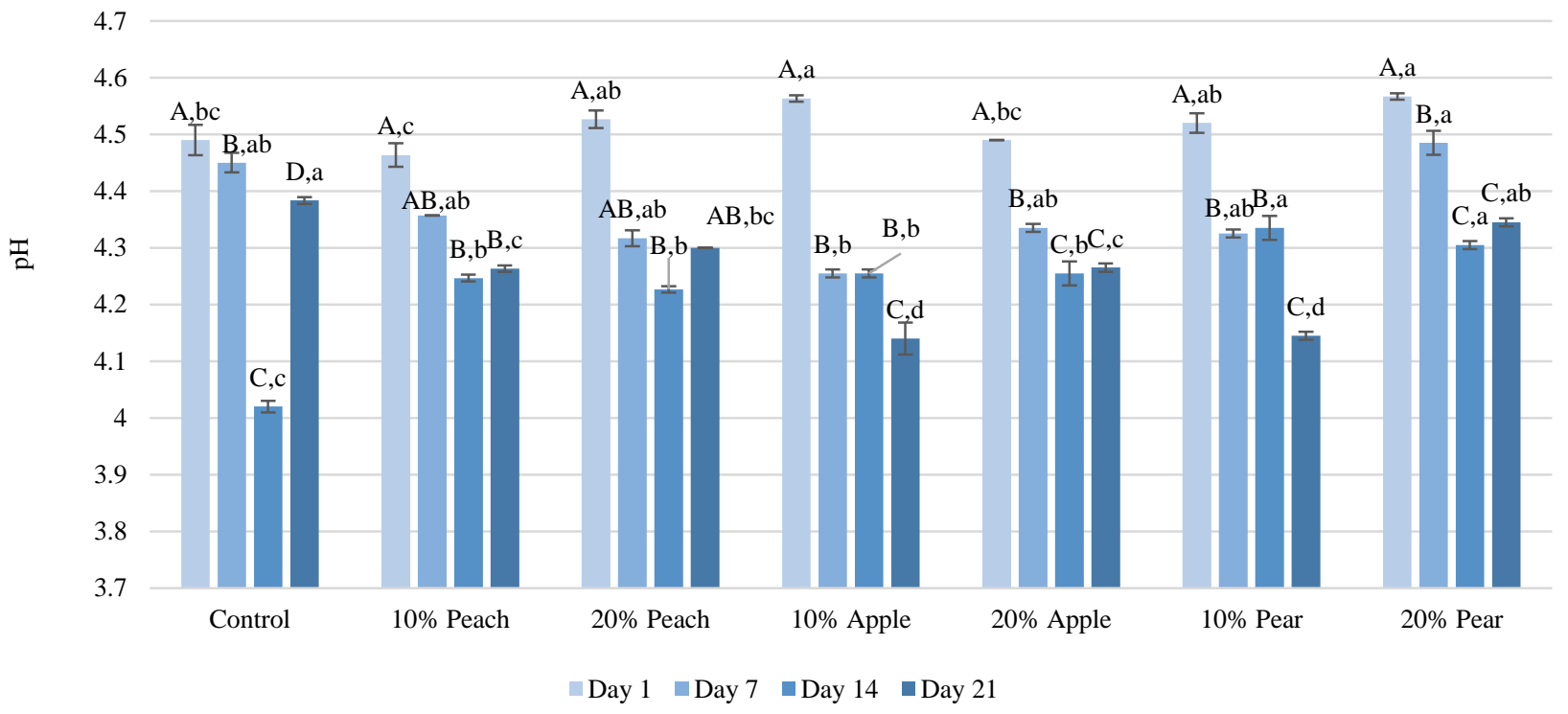

Figure 1. pH values of yoghurt samples during storage

Lower-case letters present the differences between the different samples in the same storage time and upper-case letters show differences between the storage times of each sample $(\mathrm{P}<0.05)$. 


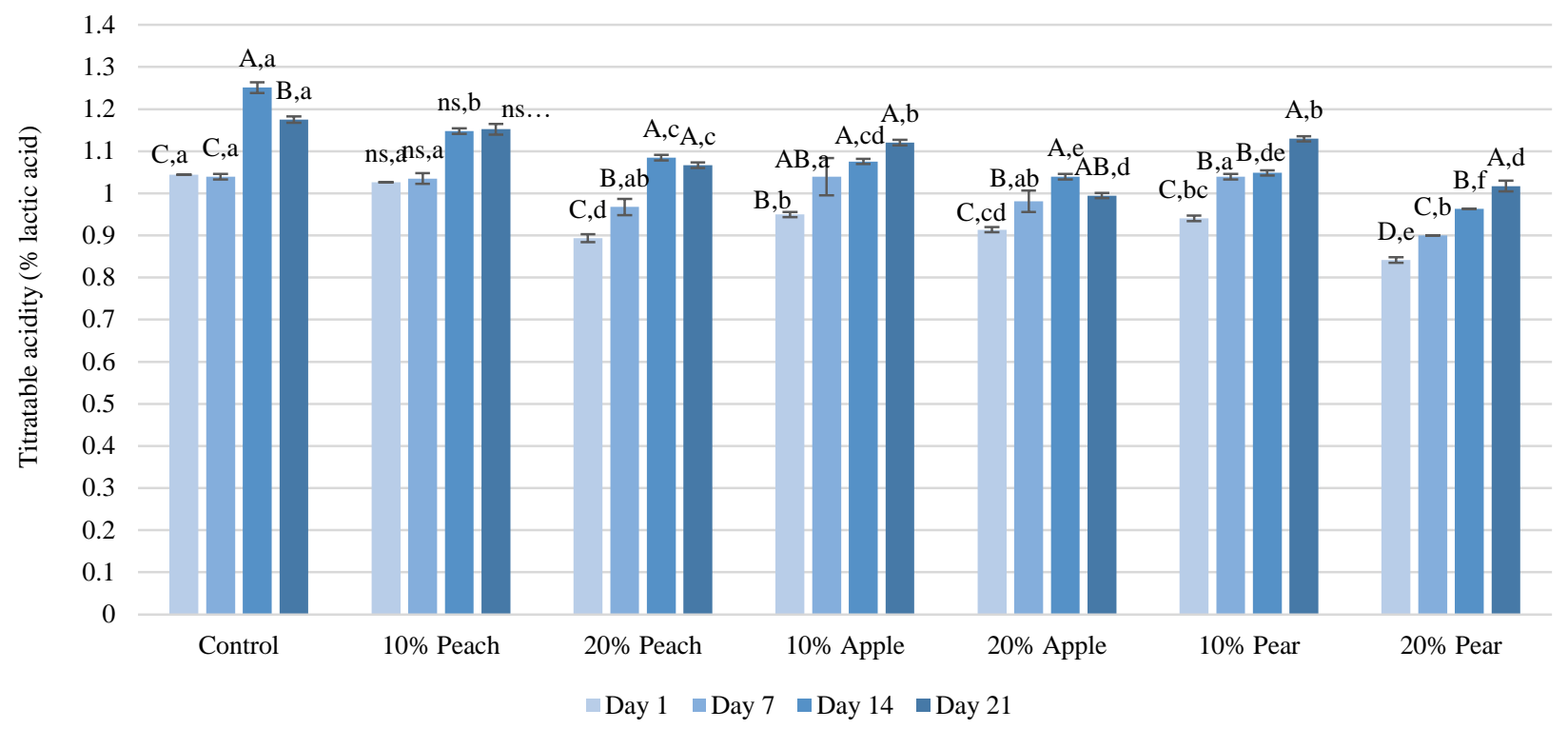

Figure 2. Titratable acidity (\% lactic acid) of yoghurt samples during storage

Lower-case letters present the differences between the different samples in the same storage time and upper-case letters show differences between the storage times of each sample $(\mathrm{P}<0.05)$. The difference between storage days in the $\mathrm{pH}$ of the yogurt sample containing $10 \%$ peach puree was insignificant $(\mathrm{ns})(\mathrm{P}>0.05)$

Çakmakçı et al. (2012) produced probiotic yoghurt by adding B. bifidum, $L$. acidophilus and yoghurt starters, added $15 \%$ banana marmalade after fermentation and kept it at $4^{\circ} \mathrm{C}$ for 14 days. The number of $B$. bifidum was above $10^{6}$ in the yoghurt only B. bifidum added decreased rapidly after the $7^{\text {th }}$ day of storage and dropped below $10^{4}$ on the $14^{\text {th }}$ day of storage. The number of $B$. bifidum was above $10^{6}$ in the yoghurt only B. bifidum added, decreased rapidly after the $7^{\text {th }}$ day of storage and dropped below $10^{4}$ on the $14^{\text {th }}$ day of storage. Similar results were obtained in yoghurt, where two probiotic cultures were used together. Banana yoghurts with probiotic cultures lost their probiotic properties after the $7^{\text {th }}$ day. More research should be carried out for possible interactions between selected strains to produce a dairy product, the selection of the best combination (s) and optimization of the processes and their survival times during cold storage. Because these bacteria must reach the intestinal tract to perform their probiotic roles (Saccaro et al., 2009).

Research indicates that probiotic bacteria and especially bifidobacteria are not sufficiently viable in yoghurt preparations. It is claimed that there are various factors that affect the viability of probiotic bacteria in yoghurt, including the acid and hydrogen peroxide produced by the yoghurt bacteria, the amount of oxygen in the product and the oxygen permeability of the package (Shah and Lankaputhra, 1997).

Cruz et al. (2013) produced yoghurt by yoghurt starters, B. longum and $L$. acidophilus inoculating. Then, they stored the yoghurts in 4 plastic packages with different oxygen permeability for 28 days. While there was no significant change in the number of yoghurt starters during storage, there was a decrease in the number of $B$. longum and $L$. acidophilus. The decrease in the number of probiotic bacteria was higher in yoghurt stored in high permeability packaging. In probiotic products, the amount of oxygen in the package should be kept to a minimum to prevent toxicity and the development of microorganisms and to protect the functionality of the product. In this case, the viability of $L$. acidophilus and bifidobacteria is negatively affected in fermented milk products (Dave and Shah, 1997). It has been determined that products formed as a result of lipid peroxidation damage DNA (Zayed and Roos, 2004). Therefore, a combination of vacuum storage and antioxidant is effective to minimize oxidation and maximize probiotic viability during storage (Weinbreck et al., 2010). The use of packaging materials with low oxygen permeability can be considered as the addition of oxygen scavengers and preventing oxygen transfer to the product during production (Talwalkar et al., 2004). While dissolved oxygen levels in HDPE packages increased significantly, oxygen levels in glass bottles remained at low levels for 35 days storage. In that study, it has been determined that the most suitable temperature for storing yoghurts containing B. lactis BB-12 is $+8^{\circ} \mathrm{C}$ (Mortazavian et al., 2007). So, Bifidobacterium cells cannot resist to low storage temperatures (Akan and Kını, 2015). In current study, probiotic yoghurts were stored at $+4^{\circ} \mathrm{C}$. The use of plastic ambalage in the fermentation and storage of samples and also low storage temperature for bifidobacteria may be one of the reasons for the decrease in probiotics.

The FDA recommends that the amount of probiotics in probiotic foods should be at least $10^{6} \mathrm{CFU} / \mathrm{mL}$ at the time of consumption. Considering the effect of storage on the digested amount and probiotic viability, it has been stated that the amount required for the probiotic effect in the human organism should be at least $10^{8}-10^{9}$ (Tripathi and Giri, 2014). It is recommended to consume 100 grams of probiotic products daily for approximately $10^{9}$ live probiotics to enter the digestive system (Akan and Kınık, 2015).

In current study, considering the sum of $L$. paracasei and Bifidobacterium spp. numbers, the control yoghurt preserved its probiotic characteristic until the $14^{\text {th }}$ day of the storage. It is understood that fruit yoghurts can be consumed as probiotic yoghurt before the $7^{\text {th }}$ day of storage. In current study, it was determined that it is more 
appropriate to choose peach and then apple as the fruit that can be used in terms of having probiotic yogurt feature. It is more appropriate that the rate of fruit to be used is $20 \%$. Since the L. delbrueckii ssp. bulgaricus count was higher in samples with $10 \%$ peach and apple puree, the probiotic bacteria count may have been lower Especially, peach puree can be recommended for freshly consumed fruit probiotic yogurts. Considering the structural features, it is more appropriate to use $10 \%$ fruit puree.

\section{Conclusions}

Probiotic dairy products, especially probiotic yoghurt, are increasingly consumed in developed countries. Its consumption, especially in childhood, will contribute to the healthier growth of new generations. Recently, adding fruits is a very common method to make dairy products more nutritious and more attractive. If the fruits are added to probiotic products, they will also serve as prebiotics in the product. In order for yoghurt with fruit to be consumed as probiotic yoghurt for a longer time, the number of added probiotic bacteria should be increased and yoghurts should be stored under appropriate conditions.

\section{References}

Akan E, Kınık O. 2015. Factors effecting probiotic viability during processing and storage of food. Celal Bayar University Journal of Science, 11(2): 155-166. http://doi.org/10.18466/ cbujos.833.80.

Alegre I, Viñas I, Usall J, Anguera M, Abadias M. 2011. Microbiological and physicochemical quality of fresh-cut apple enriched with the probiotic strain Lactobacillus rhamnosus GG. Food Microbiology, 28(1):59-66. http://doi. org/10.1016/j.fm.2010.08.006.

Brückner-Gühmann M, Benthin A, Drusch S. 2019. Enrichment of yoghurt with oat protein fractions: Structure formation, textural properties and sensory evaluation. Food Hydrocolloids, 86:146-153. http://doi.org/10.1016/j.foodhyd 2018.03.019.

Canganella F, Giontella D, Nespica ML, Massa S, Trovatelli LD. 2000. Survival of Lactobacillus acidophilus and Bifidobacterium infantis in yogurts manufactured from cowmilk and soymilk during storage at two temperatures. Annals of Microbiology, 50:43-53.

Celik EE. 2013. Determination of antioksidant capacity and regeneration behaviour of bioactive materials bound to dietary fibers with quencher procedure. MSc Thesis, Hacettepe University, The Graduate School of Natural and Applied Sciences, Ankara, Turkey.

Celik S, Bakirci I. 2003. Some properties of yoghurt produced by adding mulberry pekmez (concentrated juice). International Journal of Dairy Technology, 56(1):26-29. http://doi.org/10. 1046/j.1471-0307.2003.00070.x.

Ceyhan N, Alıc H. 2012. Intestinal microflora and probiotics. Turkish Journal of Scientific Reviews, 5(1):107-113.

Comak Gocer EM, Ergin F, Ascı Arslan A, Kücükcetin A. 2016. Effect of different incubation temperature and final incubation $\mathrm{pH}$ on physicochemical and microbiological properties of probiotic yogurt. Academic Food Journal, 14(4):341-350.

Cruz AG, Castro WF, Faria JAF, Bolini HMA, Celeguini RMS, Raices RSL et al. 2013. Stability of probiotic yogurt added with glucose oxidase in plastic materials with different permeability oxygen rates during the refrigerated storage. Food Research International, 51(2): 723-728. http://doi.org/ 10.1016/j.foodres.2013.01.028.
Çakmakçı S, Çetin B, Turgut T, Gürses M, Erdoğan A. 2012. Probiotic properties, sensory qualities, and storage stability of probiotic banana yogurts. Turkish Journal of Veterinary and Animal Sciences, 36(3): 231-237. http://doi.org/10.3906/vet1007-2.

Dave R, Shah N. 1996. Evaluation of media for selective enumeration of Streptococcus thermophilus, Lactobacillus delbrueckii ssp. bulgaricus, Lactobacillus acidophilus and bifidobacteria. Journal of Dairy Science, 9(9): 1529-1536. http://doi.org/10.3168/jds.S0022-0302(96)76513-X.

Dave RI, Shah NP. 1997. Effectiveness of ascorbic acid as an oxygen scavenger in improving viability of probiotic bacteria in yoghurts made with commercial starter cultures. International Dairy Journal, 7(6-7): 435-443. http://dx.doi. org/10.1016/S0958-6946(97)00026-5.

Debashis Kumar DR, Tanny S, Moriom A, Mojaffor H, Habiba K, Manik CR. 2015. Quality evaluation of yogurt supplemented with fruit pulp (banana, papaya and water melon). International Journal of Nutrition and Food Sciences, 4(6):695-699 http://dx.doi.org/10.11648/j.ijnfs.20150406.25.

Demirci T, Aktaş K, Sözeri D, Öztürk Hİ, Akın N. 2017. Rice bran improve probiotic viability in yoghurt and provide added antioxidative benefits. Journal of Functional Foods, 36(2017):396-403. http://dx.doi.org/10.1016/j.jff.2017.07. 019.

Do Espirito Santo AP, Perego P, Converti A, Oliveira MN. 2011. Influence of food matrices on probiotic viability - a review focusing on the fruity bases. Trends in Food Science and Technology, 22(7):377-385. http://doi.org/10.1016/j.tifs. 2011.04.008.

Do Espírito Santo AP, Perego P, Converti A, Oliveira MN. 2012. Influence of milk type and addition of passion fruit peel powder on fermentation kinetics, texture profile and bacterial viability in probiotic yoghurts. LWT-Food Science and Technology, 47(2):393-399. http://doi.org/10.1016/j.lwt. 2012.01.038.

Duzgunes O, Kesici T, Kavuncu O, Gurbuz F. 1978. Research and experiment methods (Statistic Methods II): Ankara University Agricultural Department, Ankara, Turkey.

Helrich K. 1990. Official methods of analysis of AOAC. 15th edition. Arlington: AOAC International. ISBN: 978093 5584424.

Kailasapathy K. 2006. Survival of free and encapsulated probiotic bacteria and their effect on the sensory properties of yoghurt. LWT-Food Science and Technology, 39(10):1221-1227. http://doi.org/10.1016/j.lwt.2005.07.013.

Karaca OB, Güzeler N, Tangüler H, Yaşar K, Akın MB. 2019. Effects of apricot fibre on the physicochemical characteristics, the sensory properties and bacterial viability of nonfat probiotic yoghurts. Foods, 8(1):33. http://doi. org/10.3390/foods8010033.

Koksal G, Gokmen Ozel H. 2008. Baby nutrition. Ankara, Turkey: Ministry of Health Publication.

Kourkoutas Y, Kanellaki M, Koutinas AA. 2006. Apple pieces as immobilization support of various microorganisms. LWTFood Science and Technology, 39(9):980-986. http://doi. org/10.1016/j.lwt.2006.02.024.

Kristo E, Biliaderis CG, Tzanetakis N. 2003. Modelling of rheological, microbiological and acidification properties of a fermented milk product containing a probiotic strain of Lactobacillus paracasei. International Dairy Journal, 13(7):517528. http://doi.org/10.1016/S0958-6946(03)00074-8.

Mortazavian AM, Ehsani MR, Mousavi SM, Sohrabvandi S, Reinheimer J. 2007. Effect of refrigerated storage temperature on the viability of probiotic microorganisms in yoghurt. International Journal of Dairy Technology, 60(2):123-7. http://doi.org/10.1111/j.1471-0307.2007.00306.x.

Larpent JP, Larpent Gourgaut M. 1997. Mémento technique de microbiologie. 3rd edition. Paris: Lavoisier Tec-Doc, Inc. ISBN: 9782743001636. 
Lee YK, Salminen S. 2009. Handbook of probiotics and prebiotics. 2nd edition. New Jersey, Canada: JohnWiley and Sons, Inc. ISBN: 9780470135440.

Lucey JA. 2004. Cultured dairy products: an overview of their gelation and texture properties. International Journal of Dairy Technology, 57(2-3):77-84. http://doi.org/10.1111/j.14710307.2004.00142.x.

Ozer B. 2006. Yogurt science and technology. Izmir, Turkey: Sidas Medya Ltd. ISBN: 9780310182504

Ozer B. 2010. Fermented Dairy Products, Probiotic Organisms and Cheese. In: Aran N (editör). Food Biotechnology. Ankara, Turkey: Nobel Publisher, pp. 220-240.

Park HK, So JS, Heo TR. 1995. Acid adaptation promotes survival of Bifidobacterium breve against environmental stress. Food Biotechnology, 4:226 - 230.

Pimentel TC, Garcia S, Prudencio SH. 2012. Effect of long-chain inulin on the texture profile and survival of Lactobacillus paracasei ssp. paracasei in set yoghurts during refrigerated storage. International Journal of Dairy Technology, 65(1):104-110. http://doi.org/10.1111/j.1471-0307.2011.007 39.x.

Rastall RA, Maitin V. 2002. Prebiotics and synbiotics: towards the next generation. Current Opinion in Biotechnology, 13(5):490-496. http://dx.doi.org/10.1016/s0958-1669(02)00 365-8

Ross RP, Desmond C, Fitzgerald GF, Stanton C. 2005. Overcoming the technological hurdles in the development of probiotic foods. Journal of Applied Microbiolog, 98(6):1410 1417. http://doi.org/10.1111/j.1365-2672.2005.02654.x.

Rybka S, Kailasapathy K. 1996. Media for the enumeration of yoghurt bacteria. International Dairy Journal, 6(8):839-850. http://doi.org/10.1016/0958-6946(96)00017-9.

Saccaro DM, Tamime AY, Pilleggi ALOPS, Olivera MN. 2009. The viability of three probiotic organisms grown with yoghurt starter cultures during storage for 21 days at $4^{\circ} \mathrm{C}$. International Journal of Dairy Technology, 62(3):397-404. http://doi.org/10.1111/j.1471-0307.2009.00497.x.

Sagdic O, Arici M. 2010. Microorganisms Used in Food Fermentation. In: Erkmen O (editör). Food Microbiology. Ankara, Turkey: Efil Publisher. pp. 407-426.

Salminen S, Von Wright A, Ouwehand A. 2004. Lactic acid bacteria. 3rd edition. New York, USA: Marcel Dekker, Inc. ISBN: 9780429146442.

Shah NP, Lankaputhra WEV. 1997. Improving viability of Lactobacillus acidophilus and Bifidobacterium spp. in yogurt. International Dairy Journal, 7(5):349-356. http://doi.org/10.1016/ S0958-6946(97)00023-X.

Shah NP, Lankaputhra WEV, Britz M, Kyle WSA. 1995. Survival of L. acidophilus and Bifidobacterium bifidum in commercial yoghurt during refrigerated storage. International Dairy Journal, 5(5):515-521. http://doi.org/10.1016/09586946(95)00028-2.
Sookkhee S, Chulasiri M, Prachyabrued W. 2001.Lactic acid bacteria from healthy oral cavity of Thai volunteers: inhibition of oral pathogens. Journal of Applied Microbiology, 90(2):172-179. http://doi.org/10.1046/j.13652672.2001.01229.x.

Talwalkar A, Miller CW, Kailasapathy K, Nguyen MH. 2004. Effect of packaging materials and dissolved oxygen on the survival of probiotic bacteria in yoghurt. International Journal of Food Science and Technology, 39(6):605-611. http://doi.org/10.1111/j.1365-2621.2004.00820.x.

Tamime AY, Barrantes E, Sword AM. 1996. The effect of starchbased fat substitutes on the microstructure of set-style yogurt made from reconstituted skimmed milk powder. International Journal of Dairy Technology, 49(1):1-10. http://doi.org/ 10.1111/j.1471-0307.1996.tb02612.x.

Tharmaraj N, Shah NP. 2003. Selective enumeration of Lactobacillus delbrueckii ssp. bulgaricus, Streptococcus thermophilus, Lactobacillus acidophilus, Bifidobacteria, Lactobacillus casei, Lactobacillus rhamnosus, and Propionibacteria. Journal of Dairy Science, 86(7):2288-2296. http://doi.org/10.3168/jds.S0022-0302(03)73821-1.

Tripathi MK, Giri SK. 2014. Probiotic functional foods: Survival of probiotics during processing and storage. Journal of Functional Foods, 9:225-241. http://doi.org/10.1016/j.jff. 2014.04.030.

Ucuncu M. 2005. Technology of dairy products. Izmir, Turkey: Meta Printing. ISBN: 9789759895136.

Unver Y, Unusan N. 2005. Research on nutrition education in preschool. Selçuk University Journal of Social Sciences Institute, 14:529-551.

Xanthopoulos V, Litopoulou-Tzanetaki E, Tzanetakis N. 2000. Characterization of Lactobacillus isolates from infant faeces as dietary adjuncts. Food Microbiology, 17(2):205-215. http://doi.org/10.1006/fmic.1999.0300

Wang X, Kristo E, LaPointe G. 2019. The effect of apple pomace on the texture, rheology and microstructure of set type yogurt. Food Hydrocolloids, 91:83-91. http://doi.org/10.1016/ j.foodhyd.2019.01.004.

Weinbreck F, Bodnár I, Marco ML. 2010. Can encapsulation lengthen the shelf-life of probiotic bacteria in dry products? International Journal of Food Microbiology, 136(3):364-367. http://doi.org/10.1016/j.ijfoodmicro.2009.11.004.

Zayed G, Roos YH. 2004. Influence of trehalose and moisture content on survival of Lactobacillus salivarius subjected to freeze drying and storage. Process Biochemistry, 39(9):10811086. http://doi.org/10.1016/S0032-9592(03)00222-X. 